\title{
US genome project does it the French way, conceding that size matters after all
}

Washington. The US human genome programme is about to take a leap into big science, reassured by the knowledge that the French have been there first. This week, the US effort is expected to announce its biggest project so far - a \$24 million, five-year grant to set up a large genome mapping centre in Cambridge, Massachusetts - that in style and in scope will resemble nothing so much as the French Généthon, the industrial-scale gene factor near Paris that has revolutionized genome research in its first year of operations (see Nature 357, 526; 1992).

The likeness is not coincidental - Daniel Cohen, the director of the Généthon, is a collaborator in the project and will split his time between the centres. But the centres share philosophical roots as well. Like the Généthon, the Cambridge centre and a new $\$ 13$ million gene mapping centre to be based at the University of Iowa are focused on 'whole genome' mapping, rather than the chromosome-by-chromosome approach that has characterized the US effort so far. This represents a significant shift in the direction of the US project, something that, not surprisingly, has already met with resistance from researchers in smaller laboratories who view the transition to large centres as a threat.

The Cambridge centre will be headed by Eric Lander, a geneticist at the Massachusetts Institute of Technology's Whitehead Institute for Biomedical Research who already has a smaller centre for research on the mouse genome. With a team co-directed by David Page, another Whitehead geneticist who headed the group that constructed the first map of the human $Y$ chromosome earlier this year, Lander will focus on obtaining a low-resolution physical map of the entire human genome, along with extending his mouse effort to obtain a high-resolution genetic map and a lowresolution physical map of the entire mouse genome.

Like the Généthon, the new US centres are taking a big-science approach to genome research. Lander's centre will combine nearly 40 researchers with robots and computer facilities to make up what will be the largest single fraction of the US effort. He has been collaborating with Cohen over the past year - the Cambridge centre will use libraries of clones developed at the Généthon - and the two scientists are setting up office space for each other in their respective facilities.

Only in their acceptance of industrial approaches to the genome do the two scientists differ markedly; Cohen, operating on private funds, has made the Généthon a gene mapping factory, with robots operated mostly by technicians and an emphasis on throughput. Lander, on the other hand, is firmly in the academic model. His centre will be run mostly by postdoctoral researchers with their own research projects. In practice, this may mean that Lander's centre may not generate the sheer volume of markers of the Généthon, but its researchers may

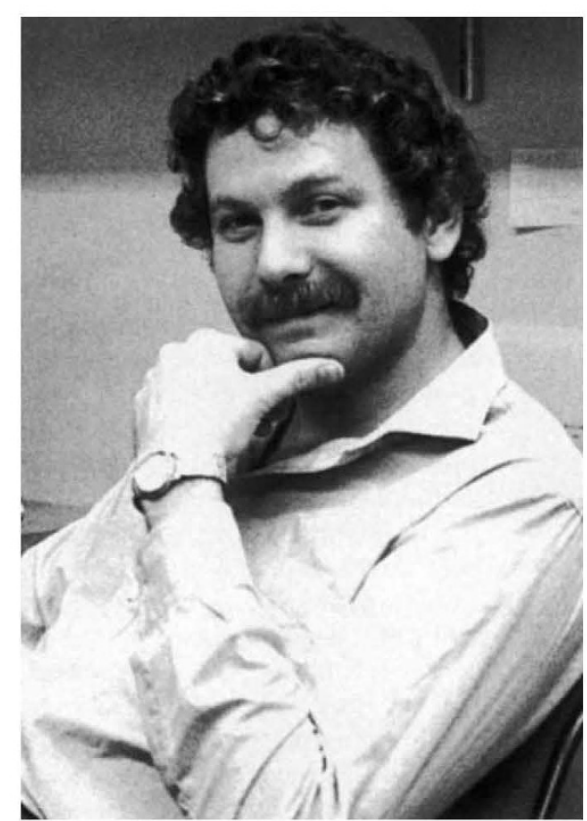

Lander's centre is taking on wholegenome targets - and the critics.

spend more time doing genome analysis and technology development.

Lander hopes to put 10,000 sequencetagged-site markers on the human genome, which would produce a physical map with 'anchors' an average of 300,000 base-pairs apart. For the mouse, he intends to obtain the same numbers of physical markers, including about 6,000 genetic markers.

The Iowa centre, based at the genetics laboratory of Jeffrey Murray, is the hub of a collaborative effort involving Iowa, the Marshfield Clinic in Marshfield, Wisconsin, Harvard University, and the Fox Chase cancer centre in Philadelphia, Pennsylvania. Together, the groups aim to obtain about 4,000 genetic markers to produce a high-resolution genetic map of the human genome.

Both larger than existing US centres and broader in scope, the two new centres have already stirred controversy. Some genome researchers - many of whom have grants due for renewal early next year - are concerned that the shift towards whole-genome mapping will leave little role for laborato- ries focusing on fractions of the genome, such as single chromosomes.

There is, in fact, some reason for concern for such scientists. Certainly, the sort of basic genetic and physical mapping assignments that the centres have taken on may preempt similar work at smaller laboratories. One of the advantages of big, highoutput centres, after all, is that they can achieve an efficiency of scale an order of magnitude above their bite-sized brethren. Lander expects that his centre will cut the cost of mapping a marker by at least a factor of four.

But that does not mean that the genome project no longer has a place for small science, Lander argues. His centre will produce only a relatively coarse map of the genome, containing only a third of the 30,000 marker target set by the genome project. Apart from the need to develop the remaining 20,000 markers, there is also much work to be done in exploring the functions and locations of the genes on the particular chromosomes. In those areas, smaller laboratories, in collaboration with dozens of other small groups, can be even more productive than large, central facilities.

A similar big-science versus little-science schism has already played out in the mouse genome community. Centres such as Lander's initially caused raised eyebrows, but when they demonstrated their willingness to share data freely long before publication, the fears that the smaller groups would be shut out of the race largely dissipated.

Indeed, Murray sees the existence of large centres as a new opportunity for some of the smaller teams in human genome research as well; not only will they now have access to vast amounts of new data, but they, too, can contemplate scaling up. His own laboratory, in fact, had been focused on chromosome four before he and his collaborators decided to join forces and propose a whole-genome approach.

Francis Collins, a University of Michigan geneticist who is under consideration as the next director of the National Center for Human Genome Research, calls the transition to large, whole-genome centres a "naturally evolving process" for the project, and notes that the timing is just as predicted in the effort's five-year plan. "A year ago everybody was wringing their hands and saying we'll never get there [to a wholegenome map]. Now they're saying we might be there a little too soon." If nothing else, he says, that is proof that it is coming right on time.

Christopher Anderson 